\title{
UM DOCUMENTO ANTIESCRAVISTA DO PRIMEIRO TERÇO DO SÉCULO XIX
}

\author{
Antonio Penalves Rocha \\ Depto. de História - FFLCH/USP
}

O artigo "Da Liberdade do Trabalho", publicado no tomo II da revista Guanabara em 1851, compendia as idéias sobre a escravidão de José da Silva Lisboa, Visconde de Cairu. Trata-se de um texto póstumo Cairu faleceu em 1835 -, e não há dados sobre a sua história, sendo que nem mesmo a Guanabara ofereceu qualquer pista sobre ele. Esta falta de informações, permite supor, com grandes chances de acerto, que ele tenha sido escrito entre os últimos anos da década de 1820 e início da de 1830, pois só poderia ter sintetizado as opiniões de Cairu sobre a escravidão depois da publicação do último dos seus livros que tratou do assunto, as Leituras de Economia Política ou Direito Econômico de 1828.

Seja como for, o artigo não mereceu as devidas atenções nem daqueles que estudaram os escritos do autor, nem tampouco dos historiadores que se debruçaram sobre as história das idéias antiescravistas no Brasil. Tanto é assim que nunca foi reeditado, embora esteja na relação de obras de sua autoria, arrolada por Alfredo do Valle Cabral, autor da mais importante bibliografia de Cairu. Deste modo, sua reedição se justifica porque atesta a existência de uma nova visão da escravidão, surgida no Brasil das primeiras décadas do século XIX, presente também em outros textos coetâneos com os quais o artigo tem pontos em comum. Estes textos são os de João Maciel Severiano da Costa na Memória sobre a necessidade de abolir a introdução de escravos africanos no Brasil, sobre o modo e condições com que esta abolição se deve fazer e sobre os meios de remediar a falta de braços que ela pode ocasionar (1821), de José Bonifácio de Andrada e Silva na Representação à Assembléia Geral Constituinte e Legislativa do Império do Brasil sobre a escravatura (1825), de Domingos Alves Branco Muniz Barreto na Memória sobre a abolição do comércio da escravatura, e de Frederico Leopoldo César Burlamaque na Memória Analítica acerca do comércio de escravos e acerca dos males da escravidão doméstica (1837), e foram reeditados em 1988 pelo Arquivo Nacional, num livro intitulado Memórias sobre a escravidão, que conta com uma "Introdução" de Graça Salgado.

Essa nova visão sobre a escravidão condenava, pela primeira vez na história do Brasil, o emprego do 
trabalho do escravo negro, embora reconhecesse, ao mesmo tempo, sua importância econômica. Desta ambigüidade, resultou uma outra: apesar de manifestar tal condenação, não sugeria a abolição imediata; seus autores limitavam-se a propor uma racionalização da exploração dos escravos, a ser viabilizada pelo Estado por meio de uma legislação específica, que promoveria o fim gradual da escravidão.

Para efeitos de análise, essa condenação tem sido enquadrada, como fez Graça Salgado, na moldura histórica formada pela constituição do Estado nacional brasileiro, que, em meio a uma multidão de questões, teria trazido à tona discussões sobre o direito de propriedade e relações de trabalho (SALGADO, 1988, p.5). Algo parecido foi feito por José Murilo de Carvalho, que analisou particularmente a Representação... de José Bonifácio como expressão da transformação da escravidão em um problema “(...) pura e simplesmente de formação de uma nação" (CARVALHO, 1988, p.296).

Não há dúvida de que esse enquadramento é necessário, porque liga a visão antiescravista às exigências concretas de um mundo definido como objeto das análises e críticas dos textos. Porém, é insuficiente, pois tira do horizonte do observador um aspecto essencial da confecção desta mesma visão: sua filiação ao antiescravismo manifestado por letrados europeus a partir da segunda metade do século XVIII. Com efeito, obtêm-se ganhos consideráveis na compreensão de textos normativos, como são todos esses acima referidos, se forem investigadas não só as ligações que eles mantêm com aspectos do mundo que os circunscreve, mas também o caráter propriamente histórico da visão que apresentam. Ou seja, a história intelectual pode prestar serviços à análise de documentos como esses, trazendo à luz uma outra dimensão do objeto investigado.

Neste caso particular, os escritores tinham diante dos olhos a escravidão negra no Brasil, mas viam-na como um sério problema do incipiente Estado nacional através de lentes fabricadas pelos princípios anti- escravistas da Ilustração européia, instalados no mundo luso-brasileiro dos princípios do século XIX. Sendo assim, seus textos expõem um duplo diálogo: um com uma tradição intelectual, fundada por escritores consagrados - tanto aqui quanto na Europa - como os formuladores das mais bem acabadas categorias explicativas sobre o assunto, como Montesquieu, Adam Smith, Jean-Baptiste Say, Charles Comte; outro, com o mundo concreto para o qual prescreviam mudanças.

Para observar o diálogo que mantiveram com as idéias européias, cumpre, antes de tudo, traçar os seus contornos, colocando sob perspectiva histórica a constituição do antiescravismo. Esses contornos permitirão identificar as fontes do artigo de José da Silva Lisboa, cuja visão, por sua vez, coincidia em muitos pontos com as dos demais escritores acima referidos.

São raríssimos os casos em que o historiador tem segurança para fixar marcos cronológicos que sejam verdadeiros divisores de água, demarcando no passado um antes diferente de um depois. Um deles é oferecido pela escravidão, pois a sua longa história pode ser divida em duas partes distintas a partir de um marco cravado nos meados do século XVIII. De fato, a partir da década de 1760, alguns letrados europeus proferiram a sentença de morte do trabalho escravo, em contraposição à censura que vez por outra esta instituição havia sofrido anteriormente durante sua existência milenar. Os princípios usados para condenála foram acolhidos pelos abolicionistas, ou seja, tiveram uma tal eficácia histórica que eliminaram todas as sociedades escravistas em pouco mais de um século depois da sentença ter sido proferida.

A fundação desse marco cronológico se deu com a publicação do Espírito das Leis de Montesquieu, que, como afirmou David Brion Davis, "mais que qualquer outro pensador, (...) colocou a escravidão na agenda da Ilustração européia" (DAVIS, 1975, p.45). Com efeito, o Livro XV, do Espírito das Leis, intitulado "Como as leis da escravidão civil têm relações com a natureza do clima" apresenta todas as opiniões 
do autor sobre essa matéria. Nele a escravidão é duramente censurada por ser contrária à moral e, por isso mesmo, violar o direito natural, por ser contrária ao espírito da monarquia, por ser um contra-senso do ponto de vista do direito civil, por ser incompatível com o cristianismo, além de considerar o trabalho escravo menos produtivo que o do homem livre.

Muito embora Montesquieu tivesse condenado a escravidão em todos esses aspectos, não chegou ao ponto de defender o seu desaparecimento; Jameson, autor do mais completo e rigoroso estudo sobre o antiescravismo de Montesquieu, localizou "a última palavra de Montesquieu sobre a escravidão" no Capítulo IX do Livro XV do Espírito das Leis (JAMESON, 1971, p.325), intitulado "O que as leis devem fazer com relação à escravidão". Todo este Capítulo é formado por uma única frase: "porém, qualquer que seja a natureza da escravidão, cumpre que as leis civis procurem dela extirpar, de um lado, os abusos e, de outro, os perigos". Assim, Montesquieu acreditava que a escravidão, empregada em certas circunstâncias, apesar de causar injustiça pelos abusos que lhe são inerentes, e representar perigos, devia ser regulada por leis para que funcionasse bem. De qualquer modo, ao analisar o conjunto de críticas à escravidão que se encontra no Livro XV, Jameson duvidou, para efeitos retóricos, que se pudesse encontrar nos trabalhos posteriores de caráter antiescravista uma idéia cujo germe já não estivesse presente no Espírito das Leis (id., ibidem, p.339).

Poucos anos depois da publicação do livro de Montesquieu, suas idéias sobre a matéria ganharam espaço no maior sucesso editorial do século XVIII. Isto porque na Enciclopédia, dirigida por Diderot e D'Alembert, o artigo "Esclavage”, escrito por Jaucourt, resumiu os diversos termos da condenação à escravidão feita pelo autor de o Espírito das Leis.

Por esse caminho, as idéias de Montesquieu contra a escravidão se difundiram, e conquistaram os escritores da Ilustração, que aprofundaram o exame da sua incompatibilidade com a moral, com o cristianismo, com o direito civil e com a governabilidade do Estado.

Paralelamente, na segunda metade do século XVIII, houve uma medida abolicionista, que nada teve a ver com as críticas desses escritores: em nome dos princípios do cristianismo, os quakers proibiram o emprego do trabalho escravo pelos membros da seita. Esta medida foi vivamente aprovada pelos que se opunham à escravidão em nome de princípios morais e racionais, e adotada como modelo a ser empregado para a extinção da escravidão negra.

Merece destaque, ainda dentro da Ilustração francesa, o tratamento dado à questão por alguns économistes - ou fisiocratas, como foram chamados a partir do século XIX. Du Pont de Nemours, editor das "Éphémérides du citoyen ou Bibliotheque Raisonée des Sciences Morales et Politiques", órgão de imprensa dos fisiocratas de 1767 a 1772, publicou aí uma série de artigos que denunciavam a baixa produtividade e os altos custos do trabalho escravo. Além dos artigos, o mesmo periódico publicou as inéditas Reflexões sobre a formação e distribuição das riquezas de Turgot (t. XI e XII, 1769 e t. I, 1770), cujo original foi alterado pelo editor, que lhe imprimiu uma orientação fisiocrática e antiescravista. Turgot protestou com veemência contra essa alteração do seu texto. Não obstante, no início do século XIX, ao editar a obra completa de Turgot, Du Pont manteve as mesmas interpolações que havia feito anteriormente nas Reflexões...; em conseqüência disto, o texto original só se tornou conhecido nos fins do século XIX, e o antiescravismo por ele exibido ficou com a chancela de Turgot.

De qualquer maneira, no século XVIII, pela mão dos fisiocratas, a crítica à escravidão se alojou na Economia Política, uma ciência social que começava a definir um território de conhecimento independente da Filosofia. É verdade que não se encontrará nos artigos das Éphémérides uma condenação puramente econômica da escravidão, dado que para os fisiocratas somente o justo era útil, e a escravidão representava 
uma violação do direito natural, tal como o pensavam. Isto significa que, em última análise, os économistes trouxeram as idéias de Montesquieu para dentro da Economia Política, acomodando-as a fundamentos diferentes daqueles que as haviam originado: o trabalho escravo é menos produtivo do que o do homem livre por atentar contra o direito natural, isto é, era economicamente nocivo por ser injusto.

É um fato bem conhecido na história da Economia Política que o descrédito da Fisiocracia se deveu à arrasadora crítica que lhe impôs a pena de Adam Smith. Mesmo assim, A Riqueza das Nações tem alguns pontos em comum com a Fisiocracia, sendo um deles a condenação da escravidão, empreendida sob o argumento de que o trabalho escravo é o mais caro de todos. Mas, não se encontrará no livro cálculos para demonstrar esta carestia, pois ela está amparada em pressupostos éticos: Adam Smith condenou a escravidão em nome da superioridade do reino das "liberdades naturais", cuja realização permitiria que cada homem procurasse melhorar a sua própria sorte; o escravo, destituído da liberdade e da propriedade da sua pessoa, era um obstáculo ao advento do melhor dos mundos, razão pela qual seu trabalho era caro. Além disso, alguns dos comentários de Adam Smith sobre a escravidão revelam seus débitos para com as idéias de Montesquieu. Assim, por exemplo, extraiu do Espírito das Leis a idéia de que a causa da escravidão residia no orgulho, um elemento constitutivo da natureza humana, e está também em A Riqueza das Nações o trecho de Montesquieu que se verá citado no artigo " $\mathrm{Da}$ Liberdade do Trabalho" de José da Silva Lisboa, sobre a superioridade do trabalho livre nas minas da Hungria em relação as da Turquia que empregavam o trabalho escravo (SMITH, 1983, II, p.280).

Nos últimos anos do século XVIII, os franceses já começavam a se esquecer das idéias dos économistes, substituídas pelos princípios de A Riqueza das Nações de Adam Smith. A primeira tradução francesa completa deste livro, de 1805, foi feita por G. Garnier, que, numa extensa introdução, pretendeu demonstrar a existência de uma unidade entre o sistema de Smith e o dos fisiocratas, atribuindo a um mal-entendido os ataques do economista escocês aos economistas franceses. De qualquer modo, os esforços de Garnier foram inúteis: "a opinião dominante dos outros especialistas sempre foi aquela que A. Blanqui exprimiu contra G. Garnier pelas seguintes palavras: 'o sistema (dos économistes) foi julgado sem apelação'”, como escreveu Oncken (ONCKEN, 1969, p. XII).

Na verdade, o episódio que assinalou o início da hegemonia do sistema de Adam Smith na história da Economia Política francesa antecedeu a própria tradução francesa de A Riqueza das Nações: trata-se da publicação, em 1803, do Traité d'Économie Politique de Jean-Baptiste Say, um trabalho inteiramente apoiado no do economista escocês. Daí para diante, os economistas franceses se submeteram aos princípios de Adam Smith. O principal efeito dessa submissão, como observou Schumpeter, foi o modesto grau de originalidade da Economia Política francesa, "sem falar das questões práticas, que, para ela, foram uma fonte de influência e lhe deram confiança em si mesma" (SCHUMPETER, 1968, p.82). Em meio as tais "questões práticas" estava o forte vínculo que a Economia Política francesa estabeleceu com o Direito, tanto que era ensinada principalmente dentro das escolas de Direito.

Resulta daí que, a partir de Jean-Baptiste Say, uma quantidade considerável de escritores como Simonde de Sismondi, Louis-Auguste Say, Storch ${ }^{1}$, Ganilh,

\footnotetext{
${ }^{1}$ Muito embora Henri- Frédérick Storch tivesse nascido em Riga, na Rússia, e prestado serviços à Coroa da sua nação como tutor dos grão-duques Nicolau (posteriormente czar) e Miguel, seu principal livro - Cours d'Économie Politique, ou Exposition des principes qui déterminent la prospérité des nations -, que aliás reunia seus ensinamentos aos príncipes, foi publicado em francês, e discutido principalmente por Jean-Baptiste Say.
} 
Dunoyer, Charles Comte, ou aderiram aos princípios formulados por Adam Smith, ou então os tomaram como ponto de referência para o desenvolvimento de suas idéias.

O que realmente importa para o tratamento do assunto em questão, é que esses autores franceses mantiveram os princípios antiescravistas da Economia Política de Adam Smith. Aliás, a conservação destes princípios não foi levada a cabo somente pelos franceses: a Economia Política Clássica inglesa também os manteve até The Slave Power de Cairnes, publicado em 1862. Sendo assim, a Economia Política Clássica elevou os princípios antiescravistas de Adam Smith à condição de categorias científicas, ao mesmo tempo que consolidou a posição da Economia Política como uma disciplina autônoma, responsável pela investigação das leis que regulam a distribuição das rendas, lucros e salários entre as classes sociais, segundo a definição que lhe deu Ricardo.

Os letrados luso-brasileiros tomaram o Espírito das Leis e a literatura econômica, principalmente a francesa das primeiras décadas do século XIX, como as principais fontes de informação sobre a escravidão. Até mesmo a edição de A Riqueza das Nações mais lida no Brasil era a da tradução francesa de G. Garnier, muito embora, desde 1811, já houvesse uma tradução brasileira da obra, feita por Bento da Silva Lisboa, e editada pela Impressão Régia, sob o título de Compêndio da Obra Riqueza das Nações.

De qualquer modo, na obra de Cairu encontra-se a reprodução de inúmeras passagens da tradução francesa de A Riqueza das Nações e menções a todos os autores franceses acima referidos, se bem que particularmente no artigo "Da Liberdade do Trabalho" tenha usado somente Montesquieu e Adam Smith.

Mas, nesse procedimento de utilizar textos dos autores europeus, Silva Lisboa não estava sozinho. Seus contemporâneos fizeram o mesmo.

João Maciel Severiano da Costa recorreu a Montesquieu, Turgot, Steuart, Adam Smith,
Herrenschwand, Jean-Baptiste Say, Bentham, Ricardo e Ganilh.

José Bonifácio de Andrada e Silva citou apenas um autor na Representação..., Poivre, cujas Voyages d'un Philosophe ou Observations sur les Moeurs et les arts des peuples de l'Afrique et de l'Asie foram resenhadas no primeiro artigo contra a escravidão escrito por Du Pont de Nemours nas Éphémérides... (t. VI, 1768); além disso, Du Pont publicou, em 1768, uma biografia intitulada Notice sur la vie de $M$. Poivre. Os fisiocratas tinham Poivre em alta consideração, e adotaram suas observações sobre a baixa produtividade e altos custos da cana-de-açúcar cultivada por braços escravos, posição esta compartilhada por José Bonifácio. Mas, afora Poivre, José Bonifácio lançou mão de argumentos econômicos contra a escravidão que podem ser encontrados nos textos dos economistas políticos fisiocratas e clássicos que trataram do assunto.

Domingos Alves Branco Muniz Barreto não se referiu a nenhum desses autores europeus; mas dialogou com eles, ao arrazoar que o tráfico negreiro não feria o direito natural, ou ao se referir, na 'Quarta Demonstração", à "economia política dos Estados", onde misturou o conceito central da Fisiocracia - ordem natural - com um princípio fundador do "sistema" de Adam Smith: "o trabalho é a fonte de toda riqueza nacional".

Frederico Leopoldo César Burlamaque confessou, com todas as letras, que a sua Memória Analítica... escorou-se no Traité de la Legislation de Charles Comte, citado incontáveis vezes no seu livro.

Neste ponto, já é possível verificar como José da Silva Lisboa se apropriou do antiescravismo da Ilustração no artigo "Da Liberdade do Trabalho", e quais são os pontos em comum entre o artigo e as Memórias dos seus coetâneos.

Cairu iniciou o artigo com uma proposição: somente o trabalho livre proporciona "benéficos efeitos". Em seguida, opôs a escravidão ao trabalho livre, partindo do princípio de que não discutiria nem 
sua conformidade com o Direito, nem tampouco a justiça da propriedade do escravo, pois "seria crueza magoar uma chaga, que talvez se não possa curar", dada a antigüidade da instituição, presente na bíblica "era dos Chams", e os horrores que sempre causa, inconciliáveis com o humanismo e o cristianismo.

Sendo assim, as primeiras linhas do artigo expõem a adesão do autor aos termos gerais da condenação religiosa e moral da escravidão, tal como fora originalmente formulada por Montesquieu. No entanto, o autor dedicou pouco espaço a este assunto, e exortou os leitores a considerá-la "somente pelos resultados econômicos". Assim, é do ponto de vista do economista político que José da Silva Lisboa quis observar a escravidão, elevando-a à condição de fenômeno universal, em vez de tratá-la especificamente como uma questão nacional brasileira. Mesmo ao propor sugestões ao soberano para que houvesse um maior aproveitamento do emprego do escravo no Brasil, não há dúvida de que Cairu acreditava estar ainda no território da Economia Política, pois seguia uma indicação de Adam Smith, para quem esta ciência era "um ramo da ciência do estadista ou do legislador", com o propósito de "enriquecer tanto os indivíduos como o soberano" (SMITH, I, 717), indicação esta consagrada pelos economistas franceses do século XIX.

Aliás, nas Leituras de Economia Política ou Direito Econômico encontra-se uma definição de Economia Política proposta pelo autor, que permite a visualização do campo dentro do qual a matéria foi analisada: ela é "a ciência das leis da constituição social, que regulam o excitamento da indústria e o aumento da inteligência dos povos, para fazerem o trabalho necessário com a menor repugnância, dificuldade e pena possível, a fim de obterem progressiva riqueza e proporcional população e prosperidade" (LISBOA, 1828, p.43). Note-se que a palavra leis adquire aqui dois sentidos: designa ao mesmo tempo fenômenos sociais regulares e constantes e leis positivas, isto é, normas instituídas pelo Estado que devem estar em confor- midade com os fenômenos. Não foi à-toa que o livro foi batizado de Leituras de Economia Política ou Direito Econômico, sendo que ao se referir ao Direito, deixava visível suas ligações com a Economia Política francesa.

De qualquer maneira, Cairu não dissertou sobre o trabalho livre propriamente dito. Opôs a ele a escravidão, e concluiu que "o trabalho do homem livre, é melhor, e mais produtivo, que o do escravo". No fim das contas, o artigo foi construído para desenvolver a idéia da inferioridade do escravo, a partir da qual o autor deduziu a superioridade do trabalho livre.

Tal desenvolvimento foi efetuado por intermédio do uso de argumentos extraídos das observações de Adam Smith e Montesquieu.

Adam Smith não está presente apenas nas citações; é da sua lavra também a viga-mestre que escora todo o artigo, segundo a qual há um "esforço natural de cada homem para melhorar a sua própria condição", sendo que os interesses pessoais coincidem com os coletivos. Para Silva Lisboa, este esforço, um aspecto da natureza humana, não se manifesta no escravo, "reduzido a estado de máquina, não esperando melhoria de condição, nem podendo adquirir propriedade". Por isso mesmo, falta-lhe motivação para se empenhar nas atividades produtivas, o que torna a escravidão nociva à "opulência e civilização".

As idéias de Montesquieu também não foram empregadas somente na citação sobre a baixa produtividade do trabalho escravo nas minas da Turquia: Silva Lisboa se inspirou no Livro XV de $O$ Espírito das Leis ao relacionar a escravidão negra das colônias americanas com a "inculcada necessidade de um clima ardente". Além disso, os fundamentos doutrinários do artigo foram dados pelas idéias de Montesquieu. Isto porque, partindo do princípio de que a escravidão é um fato universal, “(... ) chaga que talvez não se possa curar", presente tanto nos tempos bíblicos quanto nas colônias americanas, Silva Lisboa sugeriu que o soberano desse "eficaz proteção ao escravo contra a 
tirania dos seus senhores". Ou seja, a matriz usada é o Capítulo IX do Livro XV do Espírito das Leis, haja vista seu propósito de conter abusos da escravidão.

Um outro ponto de vista, obtido pelo prisma do economista político, foi acrescentado ao juízo de Montesquieu: "onde se tolera, ou se considera indispensável ter escravos, é preciso, que o jugo seja doce, para não ser inútil", apesar de o "simples cálculo de interesse" mostrar "o erro econômico de procurar enriquecer alguém com escravaturas". Deste modo, a doutrina de José da Silva Lisboa preconizava a mitigação da escravidão, pois, em conseqüência da sua inevitabilidade imposta por determinadas circunstâncias, juntamente com os danos que provoca, só mesmo a mitigação realizada por meio de leis positivas poderia assegurar que dela se obtivesse algum proveito. Além do mais, a mitigação, ao demandar leis que facilitassem a alforria, poderia promover a emancipação gradual.

Deste modo, o artigo de Silva Lisboa tem em comum com as Memórias dos outros brasileiros não somente o uso das mesmas matrizes intelectuais, basicamente as formuladas por Montesquieu e desenvolvidas dentro da Economia Política, das quais derivaram as condenações moral, religiosa e econômica da escravidão. A doutrina da mitigação, enunciada em outras termos, também está presente na Representação... de José Bonifácio e nas Memórias... de Maciel da Costa e de Burlamaque, e ausente na de Muniz Barreto, cujas atenções estavam concentradas na questão do tráfico negreiro.

Na Memória... de Maciel da Costa essa doutrina aparece em todo o artigo $1^{\circ}$ do "Parágrafo Sexto", intitulado "poupar os escravos e promover entre eles o casamento".

Na Representação... ela se revela no argumento de José Bonifácio de que o fim do tráfico negreiro acarretaria a emancipação gradual, mas, "antes que consigamos ver o nosso país livre de todo deste cancro, o que levará tempo, desde já abrandemos (grifado por mim - APR) o sofrimento dos escravos, favoreçamos, e aumentemos todos os seus gozos domésticos e civis" (SILVA, 1825, p.25).

Na Memória... de Burlamaque ela se manifesta no projeto de "melhorar a sorte dos escravos" e "mitigar os castigos" (BURLAMAQUE, 1988, pp. 182 e 183).

No que diz respeito especificamente à mitigação, esta última Memória... é superior as demais em clareza, pois explicita todo o significado da doutrina; segundo Burlamaque, "a filantrópica idéia do melhoramento da sorte dos escravos e conseqüentemente a sua emancipação gradual devem, pois, referir-se ao futuro para que se evitem os perigos reais (grifado por mim - APR) que podem e mesmo devem sobrevir"(id., p.186). Assim, além de desempenhar um papel humanitário, limitando os abusos e injustiças da escravidão, a mitigação servia também para refrear os "perigos reais". Isto equivale dizer que a idéia da mitigação encerrava dentro de si mesma todas as medidas recomendadas pela doutrina de Montesquieu sobre a escravidão, que, como se sabe, solicitava a elaboração de "leis civis (que) procurem dela extirpar, de um lado, os abusos e, de outro, os perigos".

Enfim, a doutrina da mitigação aparenta ser o mero resultado da importação das idéias de Montesquieu, um castelo construído no ar, podendo ser compreendida dentro de um tipo de genealogia das idéias. No entanto, não é bem isto. A doutrina só adquire pleno sentido se um episódio ocorrido no mundo desses homens for colocado em cena: a revolução dos escravos negros de S. Domingos dos fins do século XVIII, que, para os letrados, materializou o resultado dos perigos da escravidão. Maciel da Costa escreveu sobre o estado da ilha, "primor da cultura colonial, a jóia preciosa das Antilhas, fumando ainda com o sacrifício de vítimas humanas e inocentes..." (COSTA, 1988, p.22). José Bonifácio considerou que esses "vis escravos, (...) nada têm que perder, antes tudo que esperar de alguma revolução como a de S. Domingos" (SILVA, 1825, p.39). Embora Silva Lisboa não tenha 
feito nenhuma alusão ao episódio no artigo, certamente ele estava nos quadros da consciência do autor, que já tratara em outro lugar do "hórrido espetáculo da tremenda catástrofe da Rainha das Antilhas" (LISBOA, 1818, p.160). Assim, ao aderir aos princípios antiescravistas das luzes, construindo a doutrina da mitigação, os letrados faziam ver que não moravam nas nuvens, pois ela estava alicerçada no temor da reprodução de um Haiti no Brasil. Mas, não só pelo temor se referiram ao espisódio: dado o teor normativo dos seus textos, a idéia da revolução cumpria uma função intimidativa: caso o soberano e os estadistas não adotassem os preceitos da doutrina, seria alto o risco da explosão revolucionária; o exemplo, no fim das contas, havia sido dado objetivamente pelos fatos.

Sendo assim, ao pensar a escravidão, e fazer propostas para reformá-la, esses homens do Brasil do pri-

\section{Fontes e Bibliografia}

BARRETO, Domingos Alves Branco Muniz. Memória sobre a abolição do comércio da escravatura in Memórias sobre a escravidão, Introdução de Graça Salgado, Rio de Janeiro, Arquivo Nacional, 1988

BURLAMAQUE, Frederico Leopoldo César. "Memória Analítica acerca do comércio de escravos e acerca dos males da escravidão doméstica" In: Memórias da Escravidão, op. cit.

CABRAL, Alfredo do Valle. "Vida e Escritos de José da Silva Lisboa" in MORAES, E. Vilhena de (org.). Cairu. Rio de Janeiro, Biblioteca Nacional, 1958.

CAVALHO, José Murilo de. "Escravidão e Razão Nacional". In: Dados - Revista de Ciências Sociais, vol.31. n 3, 1988, pp. 287 a 308.

COSTA, João Severiano Maciel da. "Memória sobre a necessidade de abolir a introdução de escravos africanos no Brasil, sobre o modo e condições com que esta abolição se deve fazer e sobre os meios de remediar a falta de braços que ela pode ocasionar". In: Memórias sobre a escravidão, op. cit.

DAVIS, David Brion. The Problem of Slavery in the Age of Revolution 1770-1823. Ithaca, Cornell University Press, 1975. meiro terço do século XIX tinham os pés no chão. Como letrados não lhes faltava o aggiornamento, na medida que acompanhavam os avanços da ciência européia e os transportavam para o Brasil. Por outro lado, acomodavam-se ao mundo concreto, condenando genericamente a escravidão, sem contudo exigir o seu fim imediato. Assim, a doutrina da mitigação podia muito bem conter o perigo da revolução, se o Estado realizasse reformas que principiariam pela inclusão dos escravos no direito civil, e dar uma sobrevida à escravidão, por meio da emancipação gradual, dado que ela já havia sido "cientificamente" condenada pela Ilustração. Esta sobrevida atendia as necessidades concretas de uma sociedade escravista, mesmo porque ela havia funcionado satisfatoriamente durante cerca de três séculos no Brasil, antes de os ilustrados terem descoberto o caráter nocivo da escravidão.

JAMESON, Russel Parsons. Montesquieu et l'esclavage. Étude sur les origines de l'opinion antiesclaviste en France au XVIII $^{\text {éme }}$ siècle. New York, Burt Franklim, 1971.

LISBOA, José da Silva. Leituras de Economia Política ou Direito Econômico, Rio de Janeiro, 1828.

LISBOA, José da Silva. Memória dos Benefícios Políticos do Governo de El-Rey Nosso Senhor D. João VI. Rio de Janeiro, Impressão Régia, 1818.

MONTESQUIEU. De l'Esprit des Lois in Ouevres Complètes, Notas de Dupin, Chevier, Voltaire, Mably, Servan, La Harpe, etc., Paris, Lefebvre Libraire-Editeur, 1835.

ONCKEN, Auguste (org.). Ouevres Économiques et Philosophiques de F. Quesnay, New York, Burt Franklin, 1969.

SCHUMPETER, Joseph A. Fundamentos do Pensamento Econômico, (trad. port.) Rio de Janeiro, Zahar Ed., 1968.

SILVA, José Bonifácio Andrada e. Representação à Assembléia Geral Constituinte e Legislativa do Império do Brasil sobre a escravatura. Paris, Firmin Didot, 1825.

SMITH, Adam. Riqueza das Nações, (trad. port.) Lisboa, Fundação Calouste Gulbekian, 1983, 2 v. 


\title{
DA LIBERDADE DE TRABALHO*
}

\author{
JOSÉ DA SILVA LISBOA \\ (Visconde de Cairu)
}

O trabalho, para ter os benéficos efeitos, que a indústria humana pode racionalmente desejar e conseguir, deve ser livre, isto é, não só feito por pessoa isenta do domínio de outro, se não também por discreta escolha do mesmo trabalhador, e conseqüentemente análogo às suas inclinações, talento e circunstâncias; com a moral certeza do arbítrio próprio na disposição do respectivo produto, no que não ofende as regras essenciais da justiça. Faltando qualquer destes requisitos, o resultado do trabalho (o complexo e soma da riqueza particular e pública) vem a ser incomparavelmente inferior ao que se obtém, quando eles se reúnem.

Não entrarei no exame (alheio do meu instituto) se é lícita a escravidão, e se são justos os títulos, com que se tem ela introduzido e perpetuado ainda entre nações cultas. Seria crueza magoar uma chaga, que talvez se não possa curar. Sei que já vem, como o barbarismo e violência, da era dos Chams ${ }^{2}$, e que ao prin-

\footnotetext{
* A atualização ortográfica foi a única alteração feita no artigo por esta transcrição. Foram mantidas, portanto, a pontuação original, os itálicos e mesmo algumas passagens em que parece haver erro de impressão. A tradução dos trechos em latim foi feita do Prof. Dr. Norberto L. Guarinello, a quem quero registrar o meu agradecimento. Na nota 5, o Prof. Norberto identificou o poeta citado como sendo Juvenal, e, ao comparar o texto original com o citado por Silva Lisboa, descobriu neste último alguns erros,
}

cípio não foi assim. Sei que todos os corações honestos a horrorizam. Sei que os mesmos opressores e indiferentistas estremecem com a mais leve idéia e perigo de passarem tal sorte. Sei que não só Catões se despedaçam as entranhas, para não sofrerem tirania, se não que até os mais estúpidos Cafres terrifica a brutalidade de canibais de várias cores, dando-se a morte por milhares, e sufocando por piedade os próprios filhos, para não caírem no jugo do colono europeu. Sei que inumeráveis tribos de selvagens não se deixam seduzir de presentes e engodos dos que se jactam de descobridores dos mundos. Sei que repugna aos comuns sentimentos da humanidade, e ao espírito do cristianismo, que manda não fazer contra outro o que ninguém quer contra si; o que, posto às Divinas Escrituras, por amor da paz e subordinação, ordenassem a obediência dos senhores civis e domésticos, quer bons, quer díscolos ${ }^{3}$, e não proscrevessem

provavelmente de impressão. Optamos pela publicação do texto originalmente escrito por Juvenal.

${ }^{2}$ Genes., Cap, IX, V, 25. Maledictus Chaanan, servus servorum erit ("Maldito Canaan, será escravo de escravos").

${ }^{3}$ Obedite superioribus non tantum bonis, sed etiam dyscolis; non enim sine causa portant gladium ("Obedeça os superiores, não apenas os bons, mas também os díscolos; não é sem razão que portam a espada"). 
explicitamente tão absurdo estabelecimento, complicado com mil vícios e abusos, que não se podem arrancar de salto, sem fazerem maiores males; todavia, não é tal tolerância argumento, que justifique as barbaridades dos que a força, a fortuna, ou o erro elevaram sobre seus semelhantes. Por mais que se dissimule, e se palie instituição tão terrível, sempre os brados da sufocada humanidade apregoaram a verdade da sentença de Sêneca - Quid est servitus et mancipium, nisi nomina ex ambitione et iniuria nata? (O que são a escravidão e os escravos, senão nomes nascidos da ambição e da injustiça?) O grande Apóstolo das Gentes deu a regra dos verdadeiros cristãos - Prestai aos vossos servos o que é de justiça e eqüidade, na certeza de que tendes também um Senhor no Céu. O que faz injustiça, receberá o prêmio da sua malfeitoria. Deus não tem respeito de pessoas. Paul. Epis ad Col. Cap. III, v.25, Cap. IV., v. $1^{\circ}$. Considerai portanto a questão somente pelos resultados econômicos.

A uniforme experiência de todos os séculos e países, de concerto com a razão, mostra que o trabalho do homem livre, é melhor, e mais produtivo, que o do escravo. Por mais que o senhor se esforce e vigie, o escravo não pode resolver-se a trabalhar, se não por força e negligentemente, cedendo só por momentos à violência de quem exige e inspeta o serviço. Todo o homem aborrece, e foge do trabalho, maiormente sendo duro e contínuo. Só o amor e o interesse, ou dose forte de estupidez, resolvem trabalhar a benefício de outro. Sendo o escravo reduzido a estado de máquina, não esperando melhoria de condição, nem podendo adquirir propriedade, as faculdades do corpo e espírito ficam mutiladas e sem energia e, se se desenvolvem às vezes, é com frenesi da desesperação, para se desatinar ao suicídio, ou assassinato; e constituindo-se o próprio interesse em eterna guerra com o do senhor, o seu empenho e sagacidade consistem em subtrair-se ao serviço, evitando o castigo iminente, ou muito provável, consumindo o mais, e produzindo o menos.
Acresce o hábito (que logo se contrai e arraiga) de orgulho, continua cólera e ferocidade ou indiferença dos senhores a respeito dos escravos, os quais às vezes seviciam e assassinam, ou por pobreza, ignorância e falso cálculo, deixam fenecer à míngua, dando-lhes excessivo trabalho e miserável alimento. Estes males ainda mais se agravam, à proporção que se multiplica o número de escravos, tendo-se nações nas famílias (como ora acontece com os da Costa da África), e é necessário forçá-los ao serviço, e mantêlos em ordem, sob a guarda e proteção de um feitor, de ordinário violento e brutal ${ }^{4}$, que não tendo imediato interesse na existência e comodidade de miseráveis, que não lhe custaram dinheiro, os maltratam, e freqüentemente os destroem, e é difícil, se não impossível, reprimir-lhes os excessos de autoridade, estando na cruel alternativa, ou de não tirar vantagem de bárbaros indolentes, e desacostumados à obra regular e assídua, ou a constrangê-los ao trabalho e subordinação com dureza, que os aterre e domestique. De tais, e outros indizíveis inconvenientes, que se apôs de si tão desgraçada prática, e ignominioso labéu da humanidade, que afrouxa, se não estraga, os sagrados elementos da razão e da justiça, necessariamente resulta, que a obra do escravo não pode mais competir com a do homem livre em quantidade, perfeição e valor.

O Dr. Smith, além disso observa, que as desordens, que em geral prevalecem na economia do rico, naturalmente se introduzem no manejo de quem tem escravos; a estreita frugalidade, e constante parcimônia (base da acumulação dos fundos e progresso da opulência) naturalmente se estabelece na do homem livre e não abastado. Havendo diferentes manejos, a mesma obra requer muitos diferentes graus de despesa para se executar. A experiência de todas as idades

\footnotetext{
${ }^{4}$ Postquam nationes in familiis habemus, colluviem illam non nisi metu coercueris. - Tácito. ["Agora que temos nações na escravaria, só se pode controlar esse entulho pelo medo"].
} 
e nações mostra, que a obra do homem livre vem, enfim de conta, mais barata ao mercado, do que a feita por escravo. Assim se acha nas Colônias da América Inglesa, onde não há escravos, relativamente aos que os têm, não obstante que naquelas o salário do trabalho seja mui alto. Podia-se acrescentar que o caráter geral dos ricaços nos países de escravos se distingue, ou pela néscia e desconcertada prodigalidade, ou pela mais sórdida avareza e mesquinharia; sendo, como se diz em bom português, unhas de fome e pobretões enfatuados, maiormente com os escravos, que mais os ajudaram a viver, segundo escreveu o Poeta nos tempos mais hórridos da depravação e tirania romana ${ }^{5}$.

Observa ainda mais o Dr. Smith, que os escravos raras vezes são inventores; e todos os mais importantes melhoramentos das artes, seja em máquinas, seja no arranjamento e disposição da obra, que facilita e abrevia o trabalho, tem sido de homens livres. Quando algum escravo (diz ele) propusesse qualquer adiantamento deste gênero, o senhor seria inclinado a considerar a proposta, como sugestão à preguiça. $\mathrm{O}$ pobre escravo, em lugar de prêmio, muito provavelmente encontraria afrontas, e talvez castigo. Passava em provérbio serem os escravos preguiçosos e dorminhocos. Eles vendo passar quase todo o fruto do seu suor para a bolsa alheia, devem necessariamente preferir o - molles in gramine somnos (doces sonos na grama) - à ativa indústria, que lhes não dá proveito.

Portanto nas lavouras, minas e manufaturas, em que se empregam escravos, é necessário, em geral,

$5 \quad$..........et cogit minimas ediscere sordes; mox adquirendi; docet insatiabile votum Servorum ventres modio castigat iniquo ipse quoque esuriens; neque enim omnia sustinet unquam murida caerulei panis consumere frusta..

(...)

Sed quo divitias haec per tormenta coactas, cum furor haud dubius, cum sit manifesta phrenesis mais trabalho, para se executar a mesma quantidade de obra, do que nas exercidas por homens livres. A obra daqueles conseqüentemente vem a ser mais caras, do que a destes. Montesquieu observa, que as minas de Hungria, ainda que não tão ricas, têm sido sempre trabalhadas com menos despesas, e portanto com mais lucro, que as da Turquia, aliás vizinhas. A razão da diferença é, que as minas da Turquia são trabalhadas por escravos, e os braços destes são as únicas máquinas, que os turcos empregam, e jamais cogitarão de outras. As minas porém de Hungria são trabalhadas por homens livres, que empregam grande variedade de máquinas, pelas quais facilitam e abreviam o próprio trabalho.

A superstição, despotismo, e falsas idéias de glória, que havia entre gregos e romanos, posto blasonassem de civilização, foram os motivos de entregarem os trabalhos da agricultura, artes e comércio a escravos, considerando só digna do homem livre a profissão militar; e esta era provavelmente uma das principais causas da extrema carestia de suas manufaturas. A seda vendia-se a peso de ouro. Uma peça de linho pagava-se por um preço extravagante. As obras de lã, principalmente as pintadas de certa cor, tinham um custo desmedido, que excedem toda a crença.

O mesmo profundo autor, quando investiga as diversas vantagens de certos gêneros de cultura da América, é de parecer, que o trabalho escravo apenas poderá fazer conta na cultura do açúcar nas terras próprias a esta produção, enquanto elas se venderem na Amé-

ut locuples moriaris, egentit vivere fato?

(“... e obriga a aprender as mais ínfimas baixezas. Logo ensina o insaciável desejo de adquirir. Castiga os estômagos dos escravos com uma medida de trigo injusta e ele próprio passa fome, pois nunca consome nem mesmo os pedaços amanhecidos de pão embolorado... Mas para que essas riquezas colhidas com tal tormento? É sem dúvida uma loucura, uma evidente alucinação, viver o destino de um pobre para morrer rico"). 
rica muito baratas, pela falta de população, e o mercado geral da Europa não for abundantemente suprido deste gênero. Ele compara tais terras no estado atual do comércio, com as boas vinhas da França, cujo produto está sempre em demanda efetiva dos consumidores. A cultura do tabaco já não se acha em iguais circunstâncias; a do trigo muito menos, e portanto não pode ser feita com vantagem por escravos, nem poderá afrontar a concorrência dos países de gente livre, e de governo regular, e menos daqueles, onde não houver sobrecarrego dos impostos, nem os monstruosos monopólios mercantis e políticos, que ocasionam a opressão e miséria da maior parte do povo, que, vivendo do salário do trabalho, e sendo mal pagos, tem mais interesse de serem preguiçosos do que trabalhadores.

Já foi notado por Aristóteles na Grécia, e por Plínio, e Columela na Itália, o quanto degenerou naqueles países a cultura do trigo pela falta de lucro competente, logo que foi abandonada a escravos. Então é que se começou a queixar das esterilidades, e sentirem-se freqüentes fomes e carestias. Platão na sua República supunha necessária a extensão de planícies de Babilônia, para sustentarem-se pela cultura de escravos cinco mil homens livres com suas mulheres e filhos. Enfim é difícil, e nada seguro lucrar da miséria alheia. Repugna à sã política promover um estado contra a natureza, que apenas se pode manter por violência de quem manda, e ignorância de quem serve. Que fortuna sólida e estabelecimento tranqüilo se pode tirar de braços repugnantes, e trabalhos erradios de bárbaros e desesperados? Mal se pode ser feliz, vivendo-se à força com naturais e implacáveis inimigos domésticos, reduzidos a pouco menos da condição de brutos, correndo os senhores não só a responsabilidade de seus vícios e malfeitorias, e os riscos da fugida e morte, senão também os contínuos sustos de suas aleivosias e vinganças, de que tem havido hórridos exemplos ${ }^{6}$.
Quando o trabalho social está sob a direção de tirania doméstica e civil, incalculáveis são os males, que daí resultam à civilização, opulência e civilização.

$1^{\circ}$ Exalta-se o original barbarismo, e insolência do homem, que antes quer constranger, mandar e oprimir, do que ajustar, persuadir e bem-fazer.

$2^{\circ}$ Habitua-se a obrar pelo cego impulso do medo e violência, e não pela ilustrada coragem, e legítimo império da razão.

$3^{\circ}$ Estabelece-se interminável hostilidade entre o poderoso e o desvalido, o inerte e o industrioso, o adulador e o homem de honra; fiando-se aqueles no prestígio da força, riqueza e fraude, não tendo estes outro regresso, que a intriga, lisonja, ou aviltado sofrimento, que paralisa e amortece todas as virtudes.

$4^{\circ}$ Onde se autoriza o cativeiro, as mais baixas e vis paixões animais tomam o seu terrível ascendente. O que tem escravos, vive sempre enfezado, e tem de ordinário o espírito em cegueira e turbação. Faz-se duro, e intratável entre os iguais, vingativo e cruel com os inferiores, e inexorável com os objetos do seu furor e ignorância. Os contínuos exemplos de violência e humilhação endurece os ânimos, e habitua avilanias.

$5^{\circ} \mathrm{O}$ homem livre jamais se põe a par do escravo; e a infinita distância dos estados os repulsa de toda a racionável aliança e parceria. Por isso, onde se acha estabelecida a escravidão, o trabalho da agricultura e artes fica desonrado, como sendo a única e principal ocupação dos cativos. Daí vem, que os livres, que não podem ter escravos, ficam com pouca ou nenhuma obra honesta, sendo suplantados pela concorrência das pessoas de condição servil, dos libertos, e dos que a eles se avizinham. Não tendo assim meios fáceis de

6

Dira quod exemplum feritas produxerit aevo. (“Observe nossa época - Que exemplo produziu de terrível ferocidade"). 
subsistência, e de procriação da prole, querendo todavia viver à fidalga, em geral se distinguem pela invencível preguiça, forçado celibato, e inepto orgulho. Portanto não só a moralidade e caráter nada ganharão em tal estabelecimento, senão também a riqueza pública deve ser comparativamente inconsiderável, não obstante as vantagens do clima e terreno; porque a soma e o resultado do trabalho produtivo devem ser menores, por ser este feito por escravos, e porque a maior parte dos livres só consome, e nada produz. Por isso, onde se tem adotado a polícia da escravidão dos oriundos da África, não se vê, e é impossível formarse um corpo de nação cordata, e crescer a população segundo o seu natural progresso nos países férteis, e bem situados para o comércio.

No tempo dos vangloriosos gregos e romanos, que faziam cativos os prisioneiros de guerra, parecia impossível subsistir o império sem escravos. Eles porém ocasionaram mil convulsões e misérias. A rebelião dos hilotas na Grécia, e dos sequazes de Espártaco na Itália aterrou os mais esclarecidos Estados, e os mais hábeis generais desses tempos. Derrubado o Império do Ocidente pelos bárbaros do Norte, e estabelecida a servidão de gleba, parecia impossível prosperarem as dinastias sem tal polícia. Os países e reinos, em que esta primeiro se aboliu, ou mitigou, avantajaram-se em artes, civilização, e estabilidade política, entretanto que os mais aferrados às brutais práticas, ficaram atrasados, pobres, em anarquia ou despotismo.

Nas Colônias da América, onde o uso, ou inculcada necessidade de um clima ardente, faz continuar o cativeiro dos negros da África e seus descendentes, pareceria justo, que o soberano desse eficaz proteção ao escravo contra a tirania dos seus senhores; não só quando os maltratassem com severidades, sevícias, excesso de trabalho, falta de subsistência e curativo, como é provido pelas leis romanas, fazendo dar incontinente a liberdade aos oprimidos e desamparados, ou vendê-los com boas condições, ou ainda punir, com as competentes penas da lei os que abusassem enormemente da autoridade doméstica, segundo as circunstâncias do caso, senão também ordenar a alforria, sempre que os escravos oferecessem o seu justo preço, ainda sem terem sofrido agravo do senhor, com mais a quinta parte do mesmo preço, pela analogia da Ord. Liv. 4., Tit. 11, § 4.

Enfim, onde se tolera, ou se considera indispensável ter escravos, é preciso, que o jugo seja doce, para não ser inútil. E se todas as leis provêem a que ninguém abuse do que é seu, ainda nas coisas inanimadas, não pode um soberano, pai comum da pátria, autorizar os abusos do cativeiro, sendo indiferente a respeito das crueldades, que muitos senhores praticam, até usando de instrumentos de tortura, cuja horribilidade não é somenos da diabólica invenção de Falaris. Vêem-se senhores de um e outro sexo, quais Radamantos, Megeras, e infernais Mastigoferos, que os poetas descreveram em todas as suas fúrias, regalar o ânimo, e apascentar a vista, ordenando mortíferos suplícios a escravos, às vezes de tenra idade, por culpas leves, e de ordinário com imensa desproporção ao delito. Em quantas ocasiões se não observam as horríveis cenas, que Juvenal pintou das cruezas romanas, ainda mais desapiedadamente exercidas por mulheres $^{7}$, maiormente tendo sido escravas, como bem notou o grande Tácito - tanto saevior, quia servierat (tão mais cruelmente quanto fora escravo).

7 Pone crucem servo: meruit quo crimine servus Suplittium? Quis testis adest? Quis delutit? Audi. Nunquam de morte hominis cunctatio longa est. O demens! Itane servus homo est: nihil fecerit, esto: Hoc volo sic juben, stat pro ratione voluntas.

["Coloque o escravo na cruz. Por qual crime merecer o suplício? Quem é testemunha? Quem cometeu o delito? Ouça, nunca se hesita muito em matar um homem. Oh demente! É homem o escravo? Não fez nada? Seja, mas quero assim, assim ordeno, a vontade soprepõe-se à razão"]. 
A polícia da Espanha nas suas Colônias parece excelente modelo. Qualquer escravo, ainda não sendo seviciado, tem direito de comprar a sua liberdade, citando a seu senhor para a avaliação do preço por arbítrio de bom varão, nomeando cada um a aprazimento o seu árbitro; e no caso de discórdia, o juiz se interpõe, acordando-se com um deles. Para que cedermos aos espanhóis em justiça e humanidade? O célebre Campomanes, esclarecido ministro desta nação, tem promovido estes e outros tão dignos estabelecimentos, como se lê na obra do Sr. Joseph Townsend na sua viagem a Espanha, impressa em Londres em 1702.

Assim, cuidando-se do ensino e casamento dos escravos e libertos, havendo polícia vigilante e vigorosa, para serem bastantemente ocupados em trabalho útil; de necessidade seriam menos perversos, e mais industriosos: a certeza da beneficência do soberano os faria subordinados, agradecidos, e sustentadores do governo, as Colônias cresceriam em população de gente livre, que dariam infinidade de produtos para objetos de troca, e bem da Metrópole; e até com o tempo provavelmente contribuiriam para a civilização da África, e recíproco tráfico natural e leal; extinto o vil comércio de sangue humano, que, perpetuando o barbarismo dos vendedores e compradores, e vindo periodicamente infestar de bexigas, escorbutos, e outros miasmas, e contágios, as Colônias Européias, extinguindo milhares de crianças do país, que seriam esperança da pátria e posteridade, serve apenas de mal recrutar a população dos negros, sacrificada a mil gêneros de mortes, tormentos e agonias, e dando o repulsivo espetáculo de um povo de bárbaros, nus, famintos, preguiçosos, dissolutos e atraiçoados.

Por fim, ainda prescindindo da moralidade, o simples cálculo de interesse mostra o erro econômico de procurar enriquecer alguém com escravaturas. Quem compra escravos põe o seu cabedal em fundos perdidos. Os ingleses que contam o negócio mercantilmente, computam a mortalidade anual dos escravos da África a 10 por cento. Ainda que a terra brotasse ouro, dificilmente repararia tão grande, periódica e certa perda. Que infernal comércio é o em que se faz preciso fraudar o ventre não menos do senhor, do que o do escravo, e repelir ao hóspede para se tirar algum partido?

Dizem os viajantes da América do Norte que é ordinário ver-se a um simples jornaleiro de enxada ir para o serviço do campo, tendo por decente viático seu pão alvo, e meia galinha assada. A alegria, afabilidade, hospedagem, agasalho, franqueza, música, benfeitorias rústicas, boas estradas, civilização, aformoseiam aí as terras lavradas com braços livres. Mal se desce para onde se cultiva o açúcar e tabaco, não se encontra, senão pobreza, miséria, nudez, desconfiança e vilania. Se o célebre bispo espanhol, o piedoso Las Casas, previsse tanta desventura, não aconselharia por humanidade o comércio da cafraria, para aliviar os indígenas da América da tirania dos seus conquistadores. Até onde se teriam elevado a povoação, civilização, opulência do novo mundo, se a raça européia, primeira na escala da humanidade, tivesse dignificado as incultas regiões? Que imensidade de produções não existiriam hoje para troco das obras primas da indústria das respectivas Metrópoles e Estados civilizados?

Ainda não vi no Brasil casa, que só por escravos passasse com esplendor a netos. Não basta que o trabalho seja exercido por homem livre: é não menos preciso, que, quanto for possível seja da espontânea escolha do trabalhador, e análogo às suas propensões e talentos naturais. Esta regra é importantíssima na educação doméstica, que influi quase geralmente nos diversos modos de vida, e profissões da sociedade. Ainda que os trabalhos mais rudes do campo e das artes mecânicas, sejam, por assim dizer, homogêneas, e caibam na ordinária capacidade de todos os homens, supondo somente robustez, e algum grau de atenção nos que neles se empregam; todavia as artes liberais e as ciências requerem muito variada e particular aptidão nas pessoas, que se aplicam às mesmas; e não é 
indiferente, quanto ao final resultado, dar-se alguém a este ou àquele gênero da indústria. $\mathrm{O}$ trabalho exercido com propensão e gosto é sempre mais aturado, de boa ordem, produtivo e de primor: o que se executa com repugnância, e contra o gênio de cada um, é avesso, moroso, grosseiro e de insignificante valia. Os mesmos trabalhos do campo supõem muita variedade de conhecimentos necessários, para prosperar a lavoura, e requerem propensão e gosto dos que a eles se dedicam, para se poder tirar o maior fruto possível.

É portanto essencial à riqueza do Estado, que se deixe à cada um pleno arbítrio, não só na escolha da sua profissão, e modo de vida, dirigido unicamente pela ordinária prudência, e afeto dos pais, senão também na mudança de umas para outras ocupações, que tiverem entre si afinidade e analogia, segundo as circunstâncias; removendo-se por este modo a obstrução do trabalho e indústria, que retém em muitos países grande número de indivíduos na miséria, com desonra da humanidade, e imensa diminuição da pública opulência, e felicidade social. Assim, quando decaísse uma fábrica, um ramo do comércio, não ficariam milhares de braços sem obra e salário, nem a nação seria privada dos respectivos produtos.
Esta regra apenas poderá admitir exceção temporária nos casos de extrema necessidade pública, como de invasão de inimigos: então é evidente a urgência do governo em forçar o povo a alistamento militar e de marinha, tirando os particulares das suas ocupações ordinários: bem que em uma nação de boas leis, em que o amor da pátria tem o firme apoio das vantagens, que os indivíduos experimentam no seu governo, quando se trata do perigo do Estado, é impossível pensar, que jamais faltem voluntários, que à porfia se oferecerão ao serviço. No tempo de paz, em governo justo, não pode haver fundado receio, que, dando-se paga competente, e não sendo o soldado aviltado com disciplina de bárbaros, deixem de concorrer muitos, que, de bom grado procurem distinção e glória em uma profissão essencialmente nobre pelo seu objeto e sacrifícios, e sempre honrada na opinião de todos os povos e idades. Não careceu Roma de recrutas de força, para levar as suas águias a subjugar tão vastos países. A decadência da República data da admissão de mercenários, quando antes só os que tinham o foro de cidadão tinham direito de se alistarem nas bandeiras da pátria.

Guanabara, II (91:98), 1851. 